\title{
Changing trends in the usage of copper intrauterine contraceptive device: a five year institutional study
}

\author{
Malavika J. C.*, Prema Prabhudev \\ Department of Obstetrics and Gynaecology, SSIMS and RC, Karnataka, India \\ Received: 16 February 2017 \\ Accepted: 24 March 2017 \\ *Correspondence: \\ Dr. Malavika J. C., \\ E-mail: malavika.jcm@gmail.com \\ Copyright: (c) the author(s), publisher and licensee Medip Academy. This is an open-access article distributed under \\ the terms of the Creative Commons Attribution Non-Commercial License, which permits unrestricted non-commercial \\ use, distribution, and reproduction in any medium, provided the original work is properly cited.
}

\begin{abstract}
Background: Intrauterine contraceptive device is one of the commonest form of long acting contraceptive method (LARC) adapted by reproductive aged women all over the world today. It can be used for 5 to 10 years depending on the type of the device. Aim of the study was to study the institutional rate of copper IUCD usage, rate of removal, side effect profile, indications for removal among women seeking contraception.

Methods: The data regarding the usage of various temporary contraceptive methods were obtained from the family planning unit at our institution SSIMS\&RC, Davangere from the records between Jan 1, 2012 to Dec 31, 2016 (5 years). A careful detailed study of records was done on the usage of $\mathrm{Cu}$-IUCD.

Results: During the five year study period, 3,767 women were provided with various forms of contraceptive methods. $\mathrm{Cu}$-IUCD was the commonest method used by women accounting for $42.11 \%$ (1586 users). There was a decline in the rate of usage of $\mathrm{Cu}-\mathrm{IUCD}$ in 2015-16, with increase in the usage of injectables. 179 women requested for removal in the study period, main reason being desire to become pregnant in $73.18 \%$ (131) users. Failure rate in the study period was $0.55 \%$.

Conclusions: $\mathrm{Cu}-\mathrm{IUCD}$ is a safe and effective method of contraception adapted by women of reproductive age. The rate of removal is also low in our study. The decline in the usage of $\mathrm{Cu}$-IUCD during our study period could be attributed to increasing awareness of other methods of LARC.
\end{abstract}

Keywords: Copper IUCD, Contraception, LARC, Request for removal, Utilization rate

\section{INTRODUCTION}

The prevention of conception is contraception. And thus arises the need for awareness of various contraceptive methods either temporary or permanent to prevent conception and thereby avoid unwanted pregnancies. Arriving at a decision to use a contraceptive method is a very emotional and sensitive aspect of the reproductive life of a couple. ${ }^{1,2}$ The decision is based on knowledge, awareness and also at times based on religious beliefs. Hence a clinician needs to be empathetic about the patients beliefs, fertility needs and should be nonjudgemental. ${ }^{1}$ One of the most common reasons to adapt a temporary contraception is to space between pregnancies and other common reason being pre-existing medical illness such as severe heart disease, uncontrolled diabetes which at times may warrant them to prevent from conception. ${ }^{3}$ Amongst the temporary methods of contraception, copper IUCD is the most commonly used and is considered as safe, effective and convenient method which neither requires repetition, nor interferes with sexual activity. ${ }^{4}$

IUCDs are the most commonly used contraceptive method all over the world. It is especially opted by women who want to space between pregnancies, who are breastfeeding, who have a pre-existing medical illness wherein they require to post-pone pregnancy and those who have difficulties using other forms of temporary contraception. The main advantage lies in the fact that it 
is long acting and reversible. Also it doesn't need supervision, repetition and does not interfere with sexual activity.

IUCD s have evolved over years. The first widely used IUCD in 1920's was Grafenberg ring in Germany which was made of ring of silkworm gut and silver wire. ${ }^{5}$ This led to introduction of ota ring in Japan which was made of gold or gold plated silver. ${ }^{6}$ Then came into the market inert IUCD's in 1960's which was made of polyethylene a biologically inert plastic material and barium sulphate to render it radio-opaque. Lippe's loop was the first widely used inert IUCD. In India Lippe's loop is distributed free of cost to users through family welfare clinics since 1965 . Other inert IUCDs were saf-T coil, Mcoil. $^{6,7}$

Copper releasing IUCD was developed by Jaime Zipper and Howard Tatum in 1970's. They wrapped copper around $\mathrm{T}$ and 7 devices to improve the efficacy of the device, which was called $\mathrm{Cu}-\mathrm{T} 200$ and $\mathrm{Cu}-7$. First generation $\mathrm{Cu}-\mathrm{IUCD}$ consists of $\mathrm{Cu}-\mathrm{T} 200, \mathrm{Cu}-7$ and Multiload $\mathrm{Cu}-250$. Second generation $\mathrm{Cu}-\mathrm{IUCD}$ 's had more copper wrapped around the $\mathrm{T}$ to improve the life span and effectiveness. They came into market in late 1970's to 1980's as Multiload Cu-375, Nova-T,Cu-T 380Ag, Cu-T 380A, Cu-T380S. Multiload Cu-250 and $\mathrm{ML} \mathrm{Cu}-375$ are recommended for 3 and 5 years respectively. $\mathrm{Cu}-\mathrm{T} 380 \mathrm{~A}$ which is widely used is recommended for 10 years and is supplied free of cost by government of India.Cu-T 200 is recommended for 5 years. $^{8}$

Hormone impregnated IUCD's (Mirena) have been approved for contraceptive use. Mirena releases 20 microgm of levonorgestrel per day and is recommended for 5 years.

By far the most popular Cu-IUCD is Cu-T380A, which is widely used all over the world. Cu-T380A is a T shaped device made of polyethylene impregnated with barium sulphate. It has 314 sqmm. of copper wound around the vertical stem and 33 sqmm. on transverse arms of T. 8,9 The device is inserted into the uterine cavity by withdrawl method. The timing is insertion is usually immediately after the stoppage of menses (proliferative phase) so that pregnancy is ruled out. It can also be inserted in immediate postpartum and postabortal period, only when there are no signs of sepsis. If not inserted with in the immediate postpartum period, it can be inserted in postpartum women only after 4 weeks of delivery. $\mathrm{Cu}-\mathrm{IUCD}$ is considered safe in lactating women. It can also be used as an emergency contraception when inserted within 5 days of unprotected sexual intercourse.

The precise mechanism of action of Cu-IUCD is still not known. They are known to act locally and not systemically. $\mathrm{Cu}$-IUCD produces a foreign body reaction which causes polymorphs, giant cells, mononuclear cells, plasma cells and macrophages to appear in the endometrium, uterine and tubal fluids. These cells are known to phagocytose sperm and ova and thereby prevent fertilization. Besides this, inflammatory reaction induced in endometrium creates a hostile environment for the implantation of the fertilized ovum. Sperm motility, capacitation and survival are also affected by biochemical changes in cervical mucus produced by copper. Ovulation is not affected by $\mathrm{Cu}-\mathrm{IUCD}$. $\mathrm{Cu}-\mathrm{IUCD}$ protects against both intrauterine and ectopic pregnancy. ${ }^{9}$

Efficacy of $\mathrm{Cu}-\mathrm{T} 380 \mathrm{~A}$ is high with a failure rate of less than $1 \%$ per year with consistent/prolonged use. Women should be counselled about the chances of expulsion which is high in the first three months after insertion (1 in 20) and also high if inserted immediate postpartum. She should also be informed that $\mathrm{Cu}$-IUCD does not protect against STD's and that menstrual periods may be heavier, longer at least for the next 2-3 cycles and also about inter-menstrual and premenstrual spotting. Complications such as perforation (1.2per 1000), partial /complete expulsion, abnormal vaginal discharge and infection needs to be counselled about.

The absolute contraindication for the usage of $\mathrm{Cu}$-IUCD is present pregnancy, unexplained vaginal bleeding, active pelvic infection, any suspected gynaecologic malignancy and distorted uterine cavity by fibroids/bicornuate uterus. ${ }^{10,11}$

Hence it is important to identify the ideal candidates for $\mathrm{Cu}-\mathrm{IUCD}$ insertion, and ideal timing of insertion. Appropriate counselling coupled with identification of complications, side effects and reasons for removal are known to improve the utilization rate of the device. This study aims at determining the rate of utilization of $\mathrm{Cu}$ IUCD, side effects, reason for removal at SSIMS\&RC, Davangere, Karnataka, India.

\section{METHODS}

This is a retrospective study carried out at the family planning unit of the department of obstetrics and gynaecology at SS Institute of Medical Sceinces and Research Centre (SSIMS and RC), Davangere, Karnataka, India. SSIMS and RC is a tertiary care hospital attached to the medical college, located in davangere and caters for a female population of 2,15,195 according to 2011 census. The family planning unit is run by doctors, nurses, ancillary health workers in the department of obstetrics and gynecology. The government of India supplies copper T-380A free of cost to all the primary health centres, government hospitals, private hospitals. Women attending family planning unit are given a cafeteria of choices and copper IUCD is the most commonly opted method of contraception. Clients are given detailed information about the benefits, side effects, complications and usage period of various contraceptive methods. Clients are allowed to make an informed choice. 
The family planning unit is a part of the department of obstetrics and gynaecology and records are maintained meticulously and reviewed regularly. At first visit, counselling is done and a detailed gynaecologic and medical history is taken. General physical examination, systemic and pelvic examination is done and any contraindication for the contraceptive usage and pregnancy is ruled out. Relevant investigations are requested as per the doctor's advice. Women choosing $\mathrm{Cu}-\mathrm{IUCD}$ is fitted with the device. At our centre, $\mathrm{Cu}$ T380A is fitted as it is supplied by the government of India free of cost. Women are advised to review after the next menses to check for the threads and subsequently they are reviewed at 3 months and yearly once.
The data of the users of Cu-IUCD was obtained from family planning unit from January 1, 2012 to December 31,2016 (5 year study period). During the same time period the record of users of various other forms of contraception were also obtained. The parameters reviewed amongst the $\mathrm{Cu}$-IUCD users were age, parity, education and reasons for removal. The results were analysed using simple ratios and percentages.

\section{RESULTS}

During the 5 year study period, 3767 women were provided with various forms of contraceptive methods. Table 1 depicts the year wise distribution of various contraceptive methods during the study period.

Table 1: Summary of different contraceptive methods opted by women attending family planning unit during the 5 year study period.

\begin{tabular}{|llllllll|l|}
\hline Method & 2012 & 2013 & 2014 & 2015 & 2016 & Total & $\%$ \\
\hline IUCD & 491 & 372 & 302 & 243 & 178 & 1586 & 42.11 \\
\hline Injectables & 94 & 108 & 183 & 253 & 302 & 940 & 24.95 \\
\hline Pills & 86 & 78 & 105 & 123 & 126 & 518 & 13.75 \\
\hline Condoms & 72 & 87 & 83 & 96 & 68 & 406 & 10.77 \\
\hline Sterilization & 68 & 62 & 51 & 64 & 72 & 317 & 8.42 \\
\hline Total & $\mathbf{8 1 1}$ & $\mathbf{7 0 7}$ & $\mathbf{7 2 4}$ & $\mathbf{7 7 9}$ & $\mathbf{7 4 6}$ & $\mathbf{3 7 6 7}$ & $\mathbf{1 0 0}$ \\
\hline
\end{tabular}

$\mathrm{Cu}$-IUCD is the commonest form of contraceptive method used by women attending the family planning unit at SSIMS\&RC during the 5 year study period (20122016) with a rate of $42.11 \%$. However, the demand for $\mathrm{Cu}-\mathrm{IUCD}$ has declined from $60.54 \%$ in 2012 to $31.19 \%$ in 2015 and to $23.86 \%$ in 2016 . This can be attributed to increasing usage of injectables and pills over this time period of study and also there is increasing awareness about other LARC methods.

The age wise distribution of $\mathrm{Cu}-\mathrm{IUCD}$ in the study period is depicted in Table 2.

Table 2: Year wise age distribution of Cu-IUCD users during the study period.

\begin{tabular}{|c|c|c|c|c|c|c|c|}
\hline $\begin{array}{l}\text { Age } \\
\text { (years } \\
\text { ) }\end{array}$ & $\begin{array}{l}201 \\
2\end{array}$ & $\begin{array}{l}201 \\
3\end{array}$ & $\begin{array}{l}201 \\
4\end{array}$ & $\begin{array}{l}201 \\
5\end{array}$ & $\begin{array}{l}201 \\
6\end{array}$ & $\begin{array}{l}\text { Tota } \\
\text { l }\end{array}$ & $\%$ \\
\hline $15-19$ & 3 & 10 & 9 & 4 & 2 & 28 & 1.77 \\
\hline $20-24$ & 199 & 139 & 87 & 54 & 44 & 523 & $\begin{array}{l}32.9 \\
8\end{array}$ \\
\hline $25-29$ & 240 & 157 & 155 & 139 & 102 & 793 & 50 \\
\hline $30-34$ & 35 & 38 & 34 & 28 & 18 & 153 & 9.64 \\
\hline $35-39$ & 7 & 19 & 12 & 13 & 10 & 61 & 3.85 \\
\hline $40-44$ & 7 & 9 & 5 & 5 & 2 & 28 & 1.76 \\
\hline Total & 491 & 372 & 302 & 243 & 178 & 1586 & 100 \\
\hline
\end{tabular}

Mean age: $28.4+/-2.2$ years

Out of 1586 women using Cu-IUCD, highest number belonged to 25-29years age group accounting for $50 \%$.
Correspondingly there was a steady decline in the request for IUCD with increasing age and more than 45 years of age none of them requested for IUCD.

Evaluating the educational level amongst the Cu-IUCD users, $126(7.94 \%)$ women were found to be uneducated. $356(22.45 \%)$ women had primary education, 574 (36.19\%) women had secondary education, $272(17.15 \%)$ women went to pre-university college and $258(16.27 \%)$ women went to university college and were degree holders. This reflects that women who were educated (secondary education and above) were the ones who chose to use $\mathrm{Cu}$-IUCD. Lack of education and knowledge was consistently associated with lower utilization rate of $\mathrm{Cu}-\mathrm{IUCD}$.

In this study all women were married and none of the unmarried women opted for $\mathrm{Cu}-\mathrm{IUCD}$.

Table 3: Yearly request for $\mathrm{Cu}-\mathrm{T}$ removal among the users.

\begin{tabular}{|ll|}
\hline Year & No. of patients requesting removal \\
\hline 2012 & 38 \\
\hline 2013 & 43 \\
\hline 2014 & 36 \\
\hline 2015 & 28 \\
\hline 2016 & 34 \\
\hline Total & $\mathbf{1 7 9}$ \\
\hline
\end{tabular}


Out of 1586 women using Cu-IUCD over the 5 year study period, $719(45.34 \%)$ women were para 2, 324 $(20.43 \%)$ women were para 3, 460 (29\%) women were para 1 and $83(5.23 \%)$ women were para 4 . None of the nulligravida women chose $\mathrm{Cu}-\mathrm{IUCD}$ as the contraceptive method of choice.

During the 5 year study period, 179 women chose for the removal of $\mathrm{Cu}-\mathrm{IUCD}$ accounting for $11.28 \%$. The most common indication for request of removal was the desire to become pregnant which accounted for $73.18 \%$ (131 users). $6.7 \%$ (12 users) requested for removal and reinsertion. $6.14 \%$ (11 users) requested for removal and subsequently chose sterilization.7 women (3.92\%) requested removal for abnormal vaginal bleeding, 5 $(2.79 \%)$ of them for abnormal vaginal discharge, 6 (3.36\%) of them for lower abdominal pain. 4 (2.24\%) of them had come with missing threads and on clinical and ultrasound examination the 3 of them were found to be inside the uterine cavity and one was displaced into the cervical canal. All these 4 women requested for removal. In the 5 year study period there was only 1 failure accounting for $0.55 \%$. Uterine perforation was not recorded in any case. The low failure rate reflects that $\mathrm{Cu}$-IUCD is highly effective method of contraception. The low failure rate could also be due to loss of follow up during the study period. Table 3 shows the yearly request for removal of $\mathrm{Cu}-\mathrm{IUCD}$ and Table 4 shows indications for request of removal of $\mathrm{Cu}-\mathrm{IUCD}$.

Table 4: Indications for removal of $\mathrm{Cu}-\mathrm{IUCD}$ during the 5 year study period.

\begin{tabular}{|lll|}
\hline Indications & Number & $\%$ \\
\hline Desire for pregnancy & 131 & 73.18 \\
\hline Removal and reinsertion & 12 & 6.7 \\
\hline $\begin{array}{l}\text { Removal and request for } \\
\text { sterilization }\end{array}$ & 11 & 6.14 \\
\hline Abnormal vaginal bleeding & 7 & 3.92 \\
\hline Abnormal vaginal discharge & 5 & 2.79 \\
\hline Lower abdominal pain & 6 & 3.36 \\
\hline Missing threads & 4 & 2.24 \\
\hline Dysmenorrhea & 2 & 1.12 \\
\hline Failure & 1 & 0.55 \\
\hline Total & $\mathbf{1 7 9}$ & $\mathbf{1 0 0}$ \\
\hline
\end{tabular}

\section{DISCUSSION}

Contraceptive usage has been steadily increasing among the reproductive age women in order to avoid unwanted pregnancies and its complications. Cu-IUCD is the most common temporary form of contraception opted by women attending family planning unit at SSIMS\&RC. A total of 3767 women were offered various forms of contraception during the study period. There is a yearly decline in rate of $\mathrm{Cu}-\mathrm{T}$ usage among women and there is higher request for others forms of contraception such as injectables and pills. The demand for $\mathrm{Cu}-\mathrm{IUCD}$ has declined from $60.54 \%$ in 2012 to $31.19 \%$ in 2015 and to $23.86 \%$ in 2016 in our study. Similar finding was noted by Muthin et al and Oguanuo et al. ${ }^{12,13}$ A study conducted in zaria shows that injectable contraceptive were most commonly utilized. ${ }^{14}$

The increasing demand for a long acting contraceptive method as $\mathrm{Cu}-\mathrm{IUCD}$ in the peak of the reproductive age (25-29 years) accounting for $50 \%$ of the users and more so in educated women reflects that women seek to aspire a peak in their professional career and hence they wanted to prevent unwanted pregnancies.

Parity distribution revealed that majority of $\mathrm{Cu}-\mathrm{T}$ users belong to para 2 accounting for $45.34 \%$ and para 3 accounting for $20.43 \%$. None of the nulliparous women opted for $\mathrm{Cu}-\mathrm{IUCD}$. The main reason for adopting $\mathrm{Cu}$ IUCD among para2-para3 was the need to space between pregnancies and also to gain some time before they go for permanent sterilization.

Women who are educated more so when they had secondary education and above, chose Cu-IUCD as the method of choice for contraception. Cu-IUCD usage was less prevalent in women who were uneducated. It reflected that lack of education was associated with lesser utilization of any contraceptive method and more were the incidences of unwanted pregnancies. This finding was similar to that obtained in 2003 National Health and Demographic Survey. ${ }^{15}$

A total of 179 women requested for removal during the 5 year study period. The request for removal was commonest among those who desired to become pregnant accounting for $73.18 \%$ of removal. Removal and reinsertion was chosen in $6.7 \%$ of the users. $6.14 \%$ of users requested removal followed by permanent sterilization. Other causes for removal of $\mathrm{Cu}$-IUCD were: abnormal vaginal bleeding, abnormal vaginal discharge, lower abdominal pain and dysmenorrhoea. ${ }^{16,17}$ There were 4 cases of missing threads in the study period and 3 of them were found to be in uterine cavity and only 1 was partially displaced into the cervical canal.

Rate of failure is significantly reduced with long acting contraceptive method such as Cu-IUCD. In our study the failure rate was $0.55 \%$ for the 5 year study period. Pearl Index describes failure rate which is calculated by number of failures per 100 women using the contraceptive for a year. ${ }^{18} \mathrm{CuT} 380 \mathrm{~A}$ has a failure rate between 0.1 and $1 \%$ after the first year of use and $2.2 \%$ for $\mathrm{Cu}-\mathrm{T} 380 \mathrm{~A}$ after 12 years. ${ }^{19-21}$ The low failure rate in our study could be due to higher efficacy of Cu-T380A and also due to loss of follow up. Over the time period the patients have reported less pain and bleeding as side effects.

\section{CONCLUSION}

Desire to accept the various forms of contraception to limit the family size and to prevent unwanted pregnancies are steadily on rise. $\mathrm{Cu}-\mathrm{T} 380 \mathrm{~A}$ is the most effective and 
safe form of contraception which offers the benefit of being long acting, reversible type of contraception. The main side effect leading to removal of $\mathrm{Cu}-\mathrm{T} 380 \mathrm{~A}$ was abnormal vaginal bleeding. Although patients have reported less incidence of pain and abnormal vaginal bleeding over 5 years of study period there is a yearly decline in the rate of $\mathrm{Cu}$-IUCD usage which could be attributed to increasing awareness of other forms of long acting reversible contraceptive (LARC) methods. Efforts should be made to spread awareness amongst all reproductive age women about the benefits of using $\mathrm{Cu}$ IUCD to further improve the utilization rate.

\section{ACKNOWLEDGEMENTS}

Authors would like to thank Dr. Vijaykumar S Shabadi $\mathrm{MCh}$, for technical support and writing assistance.

\section{Funding: No funding sources}

Conflict of interest: None declared

Ethical approval: Not required

\section{REFERENCES}

1. Mishell DR. Contraception, sterilization and pregnancy termination. In: Stenchever MA, Droegemueller W, Herbst AL, Mishell Jr DR, editors. Comprehensive Gynecology, St Louis: Mosby Inc; 2001;4:295-353.

2. Nnatu S. Female sterilization techniques. J Obstet Gynecol East Cent Africa. 1984;187-191.

3. Alvares F, Brache V, Fernandez E, Guerrero B, Guiloff E, Hess R et al. New insights on the mode of action of intrauterine contraceptive devices in women. Fertil Steril. 1988;49;768-73.

4. American College of Obstetricians and Gynecologists. Statement on IUD and Infertility. Washington. 1985;10:1444-5.

5. Grafenberg E. Third Congress of World League for Sexual Reforms. London:1929;17-22.

6. Finch BE, Green H. Contraception through the Ages. London;1963:98-102.

7. Drife Fo. Handbook of Family Planning, Nancy London, Edinburgh: Churchill Livingstone; 1991.

8. ICMR: Improved utilization of Intrauterine Devices. New Delhi: ICMR; 1989;22-24.

9. WHO. Intrauterine devices: technical and managerial guidelines for services. Geneva: WHO, 1997.
Available

from

http://www.who.int/iris/handle/10665/41936

10. Reinprayoon D. Advances in intrauterine device technology. In: Hedon B, Bringer J, Mares P, editors. Fertility and Sterility. A Current Overview. London: Parthenon Publishing Group;1995:31-3.

11. Tatum HJ, Connell EB. A decade of intrauterine contraception: 1976 to 1986. Fertil Steril. 1986;46:173.

12. Muthihir JT, Iranloye T, Uduagbgbamen PFK. How long do women use the intrauterine device in Jos Nigeria? J Med Trop. 2005;7(2):13-9.

13. Oguanuo TC, Anolue FC, Ezegwui HU. Norplant contraception in the University of Nigeria Teaching Hospital Enugu: a six year review. J Coll Med. 2001;6(2):94-7.

14. Ameh N, Sule ST. Contraceptive choices among women in Zaria, Nigeria. Niger $\mathrm{J}$ Clin Pract. 2007;10(3):205-7.

15. Family Planning in Nigeria. Demographic and Health Survey: Cleveland (MD): National Population Commission and Orc Macro. 2004:61-81.

16. Burkman RT. The relationship of genital tract Actinomycetes and the development of pelvic inflammatory disease. Am J Obstet Gynecol. 1982;143:585.

17. Burkman RT. Association between intrauterine device and pelvic inflammatory device. Obstet Gynecol. 1981;57(3):269-76.

18. Sivin I, Stern J. Health during prolonged use of levonorgestrel 20 micrograms/d and the copper $\mathrm{T} \mathrm{Cu}$ $380 \mathrm{Ag}$ intrauterine contraceptive devices: a multicentre study. International Committee for Contraception Research (ICCR). Fertil Steril. 1981;36:159.

19. Van Os WAA. Intrauterine devices. In Studd J, editor. Progress in Obstetrics and Gynecology: $3^{\text {rd }}$ ed. London: Churchill - Livingstone;1983;3:294-6.

20. Farr G. New development in intrauterine devices. Netw Res Triangle Park NC. 1991;12(2):9.

21. Couthino EM, Hanson de Moura L. New leads in contraceptive research. Trop J Obstet Gynaecol. 1994;11(1)36-40.

Cite this article as: Malavika JC, Prema P. Changing trends in the usage of copper intrauterine contraceptive device: a five year institutional study. Int J Reprod Contracept Obstet Gynecol. 2017;6:1875-9. 